\title{
Entrance System for High Schools: Development of the Guttman Attitude Scale towards Local Placement
}

\author{
Meltem CoŞKUN* $\quad$ Bahattin İNAM ${ }^{* *}$ \\ Necla TURANLI ${ }^{* * *}$
}

\begin{abstract}
The foundation of transition from elementary education to secondary education is rooted in exams as well as the success gained from those exams. Although students were placed into a secondary education institution based on their exam scores in the previous exam system, with the newly-implemented 'Entrance System for High Schools' (shortly LGS in Turkish), there are two different student placements under consideration: (1) centralized placement, and (2) local placement. The purpose of the current study is to develop an attitude scale based on Guttman Scaling in order to investigate the attitudinal behaviors of the parents in the current education system. In line with this objective, a draft scale, consisting of ten items were administered to 241 parents whose children were placed into a high school in the 2017-2018 academic year. In the direction of the responses provided by the parents, four items were removed from the scale. Reliability test was conducted on the residual six items. The coefficient of reproducibility was calculated as 0,986 and scalability coefficient was 0,925 , which is considered as acceptable for the reliability of the current scale. It was concluded that Guttman Scaling for local placement (i.e., address-based placement) is a reliable research tool for measuring attitudes towards placements in secondary education.
\end{abstract}

Keywords: Entrance system for high schools, Guttman Scaling, local placement, parents, reliability.

\footnotetext{
* Orcid ID: https://orcid.org/0000-0003-4971-4963, Ress. Assist., Hacettepe University, Faculty of Education, Mathematics Education - Mathematics Teaching Program, meltemcoskun@hacettepe.edu.tr ** Orcid ID: https://orcid.org/0000-0002-6212-8013, Teacher, Turkish Ministry of National Education, bahattin.inam@gmail.com

*** Orcid ID: https://orcid.org/0000-0001-8758-9054, Prof. Dr., Hacettepe University, Faculty of Education, Mathematics Education - Mathematics Teaching Program, turanli@hacettepe.edu.tr 


\section{INTRODUCTION}

In Turkey, central examination systems are conducted for entrance to secondary education. The main of those central exams is to identify to what extent learning objectives are attained in instructed settings, and thus to place students into an upper education institution. To achieve these goals, various applications have been performed such as OKS (Selection and Placement Examination of Secondary Education Institutions), SBS (Placement Examination for High Schools), and TEOGS (Basic Education to Secondary Education Exam).

These central examinations have been subjected to alterations in terms of names, duration, content of the questions and implementation procedures. Notice that although change is at the heart of these examination systems, the main aim of the cental exams has not changed: to function as a step for students for transtions from lower secondary school to upper secondary school. It is worth mentioning that High School Entrance Exam (LGS), the last system being adopted in the 2017-2018 academic year, differs from the previous exam systems in that the current system is not constrained with the concept of "exam", but the placement of the students is different as will be elaborated in the following section.

\section{Entrance System for High Schools (LGS)}

Entrance System for High Schools (LGS) is conducted in two stages: At the first stage, a central exam is administered which graduates of lower secondary education can take. At the second stage, those graduates are placed into a secondary education institution. At the end of the academic year, the exam is held centrally and accomplished on a voluntary basis. That is, students completing $8^{\text {th }}$ grade can apply for the exam (not a compulsory one) and take it to enter a high school.

The central exam prepared on the curriculum covered at $8^{\text {th }}$ grade is implemented in two sessions. In the verbal section conducted as a morning session, 50 questions are asked while in the numeral section carried out as a noon session, 40 questions are directed to students (90 questions in total). The verbal section consists of Turkish (20 questions), Education of Religion and Ethics (10 questions), Revolution History and Kemalism (10 questions) and Foreign Language (10 questions). The numeral section is comprised of Mathematics (20 questions) and Sciences (20 questions). Once the central exam is held, student scores are calculated as "central exam score."

Following the announcement of the exam results, the process of student placements into a secondary education instutition is initiated, which is conducted in two phases: (1) Centralized placement, and (2) Local placement.

In centralized placement, it is aimed to place students into science high schools, social sciences high schools, educational institutions implementing the project and Anatolian technical programs of vocational and technical Anatolian high schools (Ministery of Education (henceforth MEB), 2018a) in accordance with their preference for these schools. Note that schools that do not accept students via centralized placement offer placements to students through local placement. Those type of schools (based on local 
placement) take certain criteria into consideration in the course of opening their doors to students; some of these factors are residential address of students, preference priority, school success grade, regularity/absenteeism and age (MEB, 2018a).

In the 2017-2018 academic year, the number of graduated $8^{\text {th }}$ graders was 1.192 .799 and 971.657 of those students were placed via centralized placement (MEB, 2018b). Following the announcement of central exam scores and centralized placement which was done based on superiority of scores, local placement was held. Figure 1 shows the percentages of these two placements as observed in Entrance System for High Schools (LGS) in the 2017-2018 academic year.

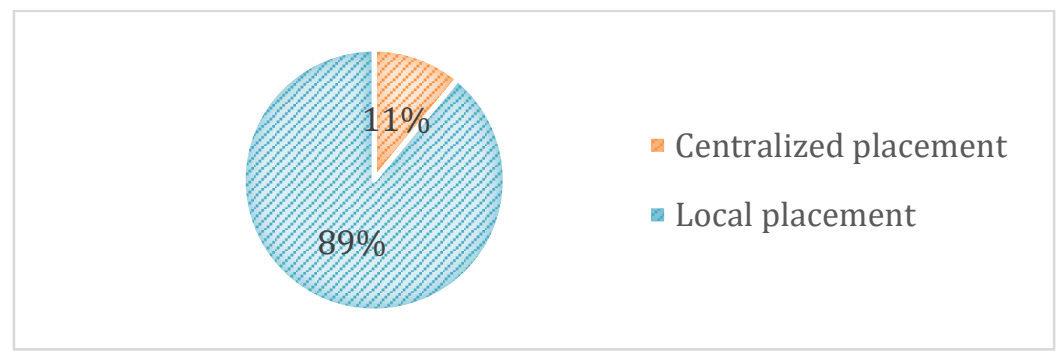

Figure 1. Percentages of two placements in Entrance Exam for High Schools (LGS) in 20172018

In the applied LGS, 1.066.899 students (MEB, 2018b) were placed into a secondary education institution via local placement, and thus were impacted by the change. It should be noted that frequent changes in educational practices do not only impact students but also all stakeholders under the same education system. In the implementation of local placement, students are accepted to a high school based on their residential address. Considering the peculiar aspect of the new exam, once announced in the media and later declared to the public, the exam was labelled as "address-based placement" rather than LGS.

The impact of the new exam system was not limited to the "name", but also economic and social dimensions such as shuttle charges and change of residence emerged as a matter. In this regard, the new system has influenced parents more than previous exam applications. Moreover, regarding the academic aspect of the situation, schools have started to accept students via exam scores while before LGS, they tended to open their doors through evaluating score intervals. To put it more precisely, in the previous exam applications, high schools were relatively homogenous, but with the implementation of local placement, the criterion of exam score is eliminated, which has resulted in a more heterogenous instructional environment. It seems that how the current situation will affect student academic success will be revealed in the long run. 
It is worth mentioning that school, teacher and family are the core, influential elements in the academic success of students. Alterations made in education system aim at increasing the quality of education through development of teachers and schools (i.e., raising teachers' salary, reducing the student numbers in class); however, these practices do not necessarily affect student academic success in a positive way. It should also be noted that for students, coming from different family backgrounds is an important external factor (Hanushek \& Woessmann, 2011) in their very own success. Perera (2014) maintains that success of students is not affected by resources provided at schools, but at the same time, it is immensely impacted by students' own characteristics, the history of family background and welfare of the resided country. The author also states that besides quality of teachers and school, parents play a critical role in helping children focus on their own academic devolepment.

Earlier literature has largely focused on the role of school and family in the student success with a particular focus on family involvement in educational processes (David, 1980; Carlisle, Stanley \& Kemple, 2005) and the impact of social, cultural and economic conditions of families on student success (Perera, 2014; Çelenk, 2003; Yıldırım \& Dönmez, 2008). Previous studies have also explored educational policies; however, less is known on the changes in education systems and expectations, contentment and thoughts of families towards those newly-implemented applications (David, 1980). To the best of our knowledge, no studies to date have focused on the attitudes of parents towards changes in educational systems. Set against this background, the current study aims to develop an attitude scale based on Guttman Scaling to explore attitudes of parents whose children were placed into a high school via local placement. As our research participants are parents with different educational backgrounds, the targeted scale is designed as Guttman scaling to secure comprehensibility of the research tool.

\section{METHOD}

\section{Developing Guttman Scale}

Guttman scale was developed by Louis Guttman, and first used for the American Army (Guttman, 1944; Guttman \& Suchman, 1947). It was later utilized to reveal general attitudes of society towards any matter at hand. It is an ordinal scale where items are arranged in such a way that participants are required to agree or disagree with the statements (Guttman, 1944). The most distinguishing characteristic of the scale is that a response provided by the respondent on one item might reason some inclinations on the rest of the items (Tavşancll, 2005). That is, as statements are arranged in a hierarchical order, someone who agrees with one item will also agree with lower-order, less extreme items. This feature of the scale demonstrates its very own cumulative structure.

\section{Developing the Items}

As in all of the scaling methods, the first stage is to develop a set of items that reflect the focus for the scale. At this stage, 10-12 items are to be developed towards the targeted 
attitude (Şencan, 2005). Accordingly, an open-ended question (i.e., what do you think/how do you feel about address-based placement?) was posed to 50 parents via online resources. The received responses were analyzed by the researchers. Note that answers that sounded immoral or did not reveal much enough about attitudes were removed from the item set. The analysis continued with the rest of the fit responses. Considering the statements targeting at attitudes, a 11 -item scale was developed. Two language experts were consulted to ensure that correct grammar and intelligibility of the items were achieved. Rather than using the term "local placement" in the items, "addressbased placement" was deployed as a concept as it is used and known more commonly in society. At the last stage, four experts on assesment and evaluation were consulted to finalize the set of items. Based on the feedback received from them, the item (i.e., I am thankful as my child goes to a high school due to address-based placement) is removed from the set as it might damage the unidimensional nature of the scale, and thus a 10-item draft scale was produced to measure the attitudes towards current focus (i.e., addressbased placement). Once the final scale items were selected, two categories were presented for respondents to check the items, namely "I agree" and "I don't agree." Table 1 presents the draft version of Guttman attitude scale towards transition to a secondary education institution.

Table 1.

Draft Scale of Parents' Attitudes towards Local (Address-based) Placement

\begin{tabular}{|c|c|c|}
\hline Items & I agree & I don't agree \\
\hline $\begin{array}{l}\text { 1. I am joyful as my child goes to a high } \\
\text { school due to address-based placement. }\end{array}$ & ( ) & ( ) \\
\hline $\begin{array}{l}\text { 2. I am worried as my child goes to a high } \\
\text { school due to address-based placement. }\end{array}$ & ( ) & () \\
\hline $\begin{array}{l}\text { 3. I am anxious as as my child goes to a high } \\
\text { school due to address-based placement. }\end{array}$ & ( ) & () \\
\hline $\begin{array}{l}\text { 4. I am happy as my child goes to a high } \\
\text { school due to address-based placement. }\end{array}$ & ( ) & ( ) \\
\hline $\begin{array}{l}\text { 5. I am nervous as my child goes to a high } \\
\text { school due to address-based placement. }\end{array}$ & ( ) & ( ) \\
\hline $\begin{array}{l}\text { 6. I am content as my child goes to a high } \\
\text { school due to address-based placement. }\end{array}$ & ( ) & () \\
\hline $\begin{array}{l}\text { 7. I am restless as my child goes to a high } \\
\text { school due to address-based placement. }\end{array}$ & ( ) & ( ) \\
\hline $\begin{array}{l}\text { 8. I am sad as my child goes to a high school } \\
\text { due to address-based placement. }\end{array}$ & ( ) & ( ) \\
\hline
\end{tabular}


9. I am at ease as my child goes to a high ( ) school due to address-based placement.

10. I feel comfortable as my child goes to a high school due to address-based placement.

As presented in Table 1, 5 out of 10 items (Item 1, Item 4, Item 6, Item 9, Item 10) indicate a positive attitude towards address-based placement while 5 items (Item 2 , Item 3, Item 5 , Item 7 , Item 8 ) demonstrate a negative attitude towards the matter at hand.

\section{Administering the Scale}

Ethical research approval was obtained in order to administer the scale. Later, the scale was directed to 270 parents residing in the province of Zonguldak whose children were placed into a secondary education institution (as 9th graders) through local placement in the 2017-2018 academic year. Table 2 presents information on the types of high schools these children were accepted to.

Table 2.

Types of High Schools Students were Placed

\begin{tabular}{ll}
\hline High School Type & Number of Students Placed via Local Placement \\
\hline Anatolian High School & 234 \\
Anatolian Vocational High School & 36 \\
\hline Total & 270 \\
\hline
\end{tabular}

Research participants (i.e., parents) were informed about the aim of the current study and they all voluntarily took part in the research as there was no risk for their involvement. It took approximately 5 minutes for each participant to provide the responses on all of the items.

\section{Item analysis}

The key to Guttman scaling is in the item analysis, which is conducted as follows: Statements of positive attitudes are coded as "I agree $=1$ " and "I don't agree $=0$ " while statements of negative attitudes are labelled as "I agree $=0$ " and "I don't agree $=1$." Response percentages (i.e., "I agree" and "I don't agree") for each item are provided in the table. Items that tend to agree or disagree less than 0.80 are removed from the set of items (Tavşancıl, 2005). 


\section{Development of Scalogram}

Scalogram analysis is the third and most important phase of Guttman scaling. The scales at this stage are for determining whether individuals differ one-dimensionally. If the scale is one-dimensional, a respondent with a positive attitude is to respond to each item in a more equal and positive way compared to other participiants (Şencan, 2005). Notice that Guttman Scale is also called as "cumulative", and when one reads from left to right across the columns (items), each scale item has a scale value associated with it obtained from the scalogram analysis. A cumulative scale is to be found in order to measure reliability of the scale. To achieve this aim, items that tend to agree or disagree less than 0.80 are removed from the items set. A table is formed that shows the responses of all the respondents on all of the items and later respondents who agree with more statements are listed at the top and those agreeing with fewer are at the bottom, which leads to "scalogram model." Once the model is designed, number of errors and sum of correct responses for each item are determined. Tavşancil (2005) defines number of errors as "damaging the cumulative structure of scalogram model" and as "the number of responses that respondents claim to disagree but are supposed to agree" and the author defines total correct guess number as "the most recurrent response number in the item set."

\section{Validity and Reliability}

The validity of the current scale was examined through multiple resources. First, items planned to be included in the scale were produced in line with the interviews conducted with the parents. Second, language and assesment/evaluation experts were consulted during the development of the items. Lastly, the scale was subjected to piloting in order to make required alterations on the draft version.

Measurement of reliability is the last phase of Guttman scaling and two coefficients (i.e., "reproducibility coefficient" and "scalability coefficient") are calculated in order to estimate the reliability (Tavşancll, 2005). Reproducibility coefficient is measured when the unidimensionality of the scale is of concern (Şencan, 2005) and it is depicted as "R." A reproducibility coefficient at least .90 indicates reliability of the scale. A scalability coefficient more than .60 is considered acceptable for the reliability of the scale (Tavşancll, 2005). All in all, Guttman Scaling is suggested as a useful methodology particularly when the unidimensionality of the scale is of concern.

\section{FINDINGS}

In what follows, we will present our findings based on the analyses conducted through developmnet of Guttman Scaling. Draft scale was administered to 270 parents. As Guttman Scale measures the extent to which a series of items is distributed onedimensionally as well as an even distribution exists for the items (equal number of positive and negative statements), participants are not supposed to provide one answer for all items. Consequently, inconsistent responses provided by 29 parents were eliminated, which resulted in a number of 241 parents participating in the study. Positive 
attitude statements were coded as "I agree=1" and "I don't agree=0" while negative attitude statements were sorted as "I agree=0" and "I don't agree=1." Percentages of agreement/disagreement for each item was calculated. Table 3 displays the results of item analysis of the draft scale.

Table 3.

Item Analysis of Draft Scale

\begin{tabular}{lcccccccccc}
\hline Item number & 1 & 2 & 3 & 4 & 5 & 6 & 7 & 8 & 9 & 10 \\
\hline $\begin{array}{l}\text { Percentage of } \\
\text { Agreement }\end{array}$ & 0,71 & 0,79 & 0,80 & 0,81 & 0,81 & 0,81 & 0,81 & 0,82 & 0,79 & 0,78 \\
$\begin{array}{l}\text { Percentage of } \\
\text { Disagreement }\end{array}$ & 0,29 & 0,21 & 0,20 & 0,19 & 0,19 & 0,19 & 0,19 & 0,18 & 0,21 & 0,22 \\
\hline
\end{tabular}

As is visible in Table 3, percentages of agreement or disagreement of Item 1, Item 2, Item 9 and Item 10 are less than 0.80 , which results in elimination of these items from the scale. However, before removing Item 2, Item 9 and Item 10, which were close to 0.80, expert opinion was received. Based on the feedback received from four experts on assessment and evaluation, these three items were eliminated from the set. In this regard, as agreement and diagreemnet value of

Item 3 , Item 4, Item 5 , Item 6 , Item 7 and Item 8 was more than 0.80 , in accordance with the expert opinion, those items were maintained to be subjected to scalogram analysis.

Following item analysis, scalogram model of Guttman Scale was constructed, which consisted of six items with high discrimination values. Scalogram modelling allows Guttman scale to be asseed how much the distribution of the observed scores on all items deviate from ideal combination. This model was designed on a rank-ordering system (i.e., from most agreed item to least agreed item) and also responses provided by the parents were subjected to descending sort in accordance with the total number of agreed responses. Erroneous responses (called as errors) that invalidated the cumulative nature of the scale were detected. Table 4 illustrates parents with erroneous answers as well as their responses. 
Table 4.

Erroneous Responses in Scalogram

\begin{tabular}{|c|c|c|c|c|c|c|}
\hline & Item 7 & Item 4 & Item 5 & Item 8 & Item 6 & Item 3 \\
\hline Parent181 & 1 & 0 & 1 & 1 & 1 & 1 \\
\hline Parent182 & 1 & 0 & 1 & 1 & 1 & 1 \\
\hline Parent183 & 1 & 1 & 0 & 1 & 1 & 1 \\
\hline Parent184 & 1 & 1 & 1 & 1 & 0 & 1 \\
\hline Parent185 & 1 & 1 & 1 & 0 & 1 & 1 \\
\hline Parent186 & 1 & 1 & 1 & 1 & 0 & 1 \\
\hline Parent187 & 0 & 1 & 1 & 1 & 1 & 1 \\
\hline Parent188 & 1 & 1 & 1 & 0 & 1 & 1 \\
\hline Parent189 & 1 & 1 & 0 & 1 & 1 & 1 \\
\hline Parent191 & 1 & 1 & 1 & 1 & 0 & 1 \\
\hline Parent194 & 1 & 0 & 1 & 1 & 1 & 1 \\
\hline Parent195 & 0 & 1 & 1 & 1 & 1 & 1 \\
\hline Parent197 & 0 & 1 & 1 & 0 & 1 & 1 \\
\hline Parent198 & 1 & 0 & 1 & 1 & 0 & 1 \\
\hline Parent199 & 1 & 1 & 0 & 0 & 1 & 1 \\
\hline Parent200 & 0 & 0 & 0 & 1 & 0 & 1 \\
\hline Parent202 & 0 & 1 & 0 & 0 & 0 & 0 \\
\hline
\end{tabular}

In table 4, cells with white fill indicate appropriate answers, cells with blue fill demonstrate errorenous agreed responses and cells with green fill display errorenous disagreed answers. More specifically, cells with green fill refer to answers that damage the cumulative nature of scalogram model as well as responses parents were supposed to answer but did not. To illustrate, the scale score of Parent181 is 5 . What it tells us is that the parent agreed with the first five items but did not continue in the same way with the rest of the scale (5 items were disagreed). However, it was observed that the parent agreed with the last statement (Item 3) and disagreed with the second statement (Item 4 ). In this sense, what emerges from this way responding is accepted as an error. In table 4, 20 errorenous responses were presented using the error detection in this way.

It is of importance that total number of correct answers as well as number of errors are detected for reliability analysis. Total number of correct responses consists of most 
repeated answer for each item. Table 5 illustrates the most recurrent responses with their numbers.

\section{Table 5.}

Number of Correct Guesses based on Items

\begin{tabular}{clc}
\hline Item number & Most repeated answer & Number of correct guess \\
\hline 7 & I don't agree & 197 \\
4 & I agree & 197 \\
5 & I don't agree & 196 \\
8 & I don't agree & 196 \\
6 & I agree & 195 \\
3 & I don't agree & 194 \\
\hline
\end{tabular}

The last stage of Guttman Scaling is reliability analysis. Notice that the values of reproducibility coefficient and scalability coefficient, an indication of reliability, are used to conduct the reliability analysis.

The Guttman Scaling, consisting of six items, showed that the responses provided by 241 parents produced a number of total correct guess as follows: $6 \times 241=1446$. A reliability criterion, R reproducibility coefficient was calculated as such:

$$
R=1-\frac{\text { Number of Errors }}{\text { Total Number of Guess }}=1-\frac{20}{1446}=0,986
$$

Another reliability criterion for Guttman Scaling is measurement of scalability coefficient and the value of minimum marginal productivity coefficient should be known to proceed with the analysis. MMR coefficient was measured as 0,813 as illustrated:

$$
\begin{aligned}
M M R=\frac{\text { Number } \text { of Correct Guess }}{\text { Total Number of Guess }}=\frac{197+197+196+196+195+194}{1446}= & \frac{1175}{1446} \\
& =0,813
\end{aligned}
$$

Scalability coefficient was calculated as follows:

Scalability coefficient $=\frac{R-M M R}{1-M M R}=\frac{0,986-0,813}{1-0,988}=0,925$

All in all, scalogram analysis was completed with a value of 0,986 for reproducibility coefficient and with a value of 0,925 for scalability coefficient. 


\section{CONCLUSION, DISCUSSION AND SUGGESTIONS}

This study set out to develop an attitude scale based on Guttman Scaling in order to explore attitudes of parents whose children were placed into a seconday education institution via local placement. To achieve this goal, an 11-item scale was developed in accordance with the online communication accomplished with the parents. One item was removed from the scale following the feedback obtained from the experts. The draft scale was constructed with the residual items (10 items in total). The research tool (i.e., scale) was administered to 270 parents and responses received from 241 parents were included in the analysis, and 10 items were subjected to item analysis.

Based on the item analysis, four items (Item 1, Item 2, Item 9 and Item 10) agreement or disagreement values of which were counted less than 0.80 were removed from the set of items (Tavşancll, 2005). The percantages of Item 2, Item 9 and Item 10 were close to 0.80 and expert opinions were received in order to decide to include or dismiss those items in the analysis. Taking the expert feedback into consideration, those items were eliminated and scalogram analysis was conducted with the residual six items.

Drawing on the analysis, the number of erroneous answers was found to be 20, which led to measurement of reproducibility coefficient and scalability coefficient, indications of reliability for Guttman scaling. A reproducibility coefficient at least 90 indicates reliability of the scale while a scalability coefficient more than .60 is considered acceptable for the reliability of the scale (Tavşancll, 2005). The reproducibility coefficient of items was found 0,986 and scalability coefficient value was observed as 0,925 . In lights of the findings, Guttman Scaling can be suggested as a useful and reliable methodology particularly when the distribution of items unidimensionally is of main concern. The final version of the scale is presented in Table 6 as "scale of parents' attitudes towards local (address-based) placement."

Table 6.

Scale of Parents' Attitudes towards Local (Address-based) Placement

\begin{tabular}{|c|c|c|}
\hline Items & I agree & I don't agree \\
\hline $\begin{array}{l}\text { 7. I am restless as my child goes to a high } \\
\text { school due to address-based } \\
\text { placement. }\end{array}$ & ( ) & ( ) \\
\hline $\begin{array}{l}\text { 4. I am happy as my child goes to a high } \\
\text { school due to address-based } \\
\text { placement. }\end{array}$ & () & ( ) \\
\hline $\begin{array}{l}\text { 5. I am nervous as my child goes to a } \\
\text { high school due to address-based } \\
\text { placement. }\end{array}$ & ( ) & ( ) \\
\hline
\end{tabular}


8. I am sad as my child goes to a high

( )

( )

school due to address-based

placement.

6. I am content as my child goes to a high

( )

( )

school due to address-based

placement.

3. I am anxious as as my child goes to a

high school due to address-based placement.

The highest and the most positive attitude score that can be obtained from the scale (consisting of 6 items) is 6. In order to score this number (i.e., 6), the response "I don't agree" is to be directed to Item 7 , Item 5 , Item 8 and Item 3 , and the answer "I agree" is to be given to Item 4 and Item 6 . The most negative score that can be obtained from the scale is 0 . In order to score this number (i.e., 0 ), Item 7, Item 5, Item 8 and Item 3 should be answered as "I agree" and Item 4, and Item 6 are to be responded as "I don't agree."

Guttman Scaling is inherently simple to understand and response time is also short due to its dichotomous structure. Based on the observations made during data collection, it was found that each participant spent approximately 5 minutes to respond to the scale and no questions were received by the parents in the course of implementation of the scale. Taking these observations into account, it might be concluded that Guttman Scaling is a useful methodology tool when it is a concern of when participants with different social and cultural backgrounds are to be exposed to a limited time to perform in the study.

The current developed scale was administered to participants located in the province of Zonguldak and Entrance Examination for High Schools (LGS) was conducted for the second time in the course of the study. Therefore, different implementations might be carried out across Turkey to further our understanding of the matter at hand.

\section{References}

Carlisle, E., Stanley, L., \& Kemple, K. M. (2005). Opening doors: Understanding school and family influences on family involvemenf. Early Childhood Education Journal, 33(3), 155-162. doi:10.1007/s10643-005-0043-1

Çelenk, S. (2003). Okul başarısının ön koşulu: Okul aile dayanışması. İlköğretim Online, 2(2), 28-34.

David, E.M. (1980). The state, the family and education. Londra: Routledge. doi:10.4324/9781315718385

Guttman, L. (1944). A basis for scaling qualitative data. American Sociological Review, 9(2), 139150. 
Guttman, L., \& Suchman, E. A. (1947). Intensity and a zero point for attitude analysis. American Sociological Association, 12(1), 57-67.

Hanushek, E. A., \& Woessmann, L. (2011). How much do educational outcomes matter in OECD countries? Economic Policy, 26(67), 427-491.

Milli Eğitim Bakanlığı. (2018a). Ortaöğretime geçiş tercih ve yerleştirme kılavuzu. http://odsgm.meb.gov.tr/meb_iys_dosyalar/2018_06/29113510_2018_YILI_TERCYH_VE_YER LEYTYRME_KILAVUZU.pdf

Milli Eğitim Bakanlığı. (2018b). 2018 Liselere geçiş sistemi (LGS) merkezi sınavla yerleşen öğrencilerin performansi. https://www.meb.gov.tr/meb_iys_dosyalar/2018_12/17094056_2018_lgs_rapor.pdf

Perera, L. D. (2014). Parents' attitudes towards science and their children's science achievement. International Journal of Science Education, 36(18), 3021-3041. doi:10.1080/09500693.2014.949900

Şencan, H. (2005). Sosyal ve davranışsal ölçümlerde güvenilirlik ve geçerlilik. Ankara: Seçkin Yayıncilık.

Tavşancıl, E. (2005). Tutumların ölçülmesi ve SPSS ile veri analizi. Ankara: Nobel Yayın Dağıtım.

Ylldırım, M. C. ve Dönmez, B. (2008). Okul-aile işbirliğine ilişkin bir araştırma (İstiklal İlköğretim Okulu örneği). Elektronik Sosyal Bilimler Dergisi, 7(23), 98-115. 
In the writing process of the study titled "Entrance System for High Schools: Development of the Guttman Attitude Scale towards Local Placement”, the rules of scientific, ethical and citation were followed; it was undertaken by the authors of this study that no falsification was made on the collected data. "Sakarya University Journal of Education Journal and Editor" had no responsibility for all ethical violations to be encountered, and all responsibility belongs to the authors and that the study was not submitted for evaluation to any other academic publishing environment. 